\title{
Severe Reduction in Number and Function of Peripheral T Cells Does Not Afford Protection toward Emphysema and Bronchial Remodeling Induced in Mice by Cigarette Smoke
}

Giovanna De Cunto, ${ }^{*}$ Benedetta Lunghi, ${ }^{*}$ Barbara Bartalesi, ${ }^{*}$ Eleonora Cavarra, ${ }^{*}$ Silvia Fineschi, ${ }^{*}$ Cristina Ulivieri, Giuseppe Lungarella, ${ }^{*}$ and Monica Lucattelli*

From the Departments of Molecular and Developmental Medicine* and Life Sciences, ${ }^{\dagger}$ University of Siena, Siena, Italy

Accepted for publication March 4, 2016.

Address correspondence to Giuseppe Lungarella, M.D. or Monica Lucattelli, Ph.D., Department of Molecular and Developmental Medicine, University of Siena, Via Aldo Moro 6, 53100 Siena, Italy. E-mail: giuseppe.lungarella@ unisi.it or monica.lucattelli@ unisi.it.

\begin{abstract}
The protein Lck ( $\mathrm{p} 56^{L c k}$ ) is a Src family tyrosine kinase expressed at all stages of thymocyte development and is required for maturation of $T$ cells. The targeted disruption of $L c k$ gene in mice results in severe block in thymocyte maturation with substantial reduction in the development of $\mathrm{CD}^{+} \mathrm{CD}^{+}$thymocytes, severe reduction of peripheral T cells, and disruption of T-cell receptor signaling with defective function of T-cell responses. To investigate the role of $\mathrm{T}$ lymphocyte in the development of cigarette smoke-induced pulmonary changes, $\mathrm{LCK}^{-/-}$mice and corresponding congenic wild-type mice were chronically exposed to cigarette smoke, and their lungs were analyzed by biochemical, immunologic, and morphometric methods. Smoking mice from both genotypes showed disseminated foci of emphysema and large areas of goblet cell metaplasia in bronchial and bronchiolar epithelium. Morphometric evaluation of lung changes and lung elastin determination confirmed that mice from both genotypes showed the same degree of emphysematous lesions. Thus, cigarette smoke exposure in the presence of severe reduction in number and function of peripheral $T$ cells does not influence the development of pulmonary changes induced by cigarette smoke. The data obtained suggest that innate immunity is a leading actor in the early development of pulmonary changes in smoking mice and that the adaptive immune response may play a role at later stages. (Am J Pathol 2016, 186: 1814-1824; http://dx.doi.org/10.1016/j.ajpath.2016.03.002)
\end{abstract}

Cigarette smoke (CS) is considered to be the main causative factor of chronic obstructive pulmonary disease (COPD) in humans. ${ }^{1,2}$ The pathogenesis of this disease is still subject to debate, and several mechanisms are involved in the development of parenchymal and airway lesions that characterize COPD. These mechanisms include protease/antiprotease and oxidant/antioxidant imbalances, increased rate of epithelial cell apoptosis, and abnormal innate or adaptive immune responses. 3

For innate and adaptive immune mechanisms, many elements of both types of response are abnormal in COPD. ${ }^{4,5}$ Although the innate immune response was long considered important in the pathogenesis of COPD, some evidence supports a role of the acquired response that requires the proliferation of T cells. ${ }^{6}$ Whether and how T cells actually contribute to COPD pathogenesis, however, remains undefined.
To investigate the pathogenic role of adaptive immune responses that require the proliferation of $\mathrm{T}$ cells in the development of smoke-induced lung changes that resemble COPD in humans, genetically engineered mice knocked out of the Lck gene were used.

The protein Lck (p56 ${ }^{L c k}$ ) is a Src family tyrosine kinase expressed at all stages of thymocyte development and is required for the maturation of $\mathrm{T}$ cells. ${ }^{7,8}$ The targeted disruption of the Lck gene results in a severe block in thymocyte maturation with a substantial reduction in the development of $\mathrm{CD}^{+}{ }^{+} \mathrm{CD} 8^{+}$thymocytes, severe reduction of

Supported by Ministry of Education, University and Research (Rome, Italy) grant 2004067923 (M.L.) and University of Siena PAR grant 122004 (M.L.).

Disclosures: None declared. 
peripheral T cells,,${ }^{9,10}$ and disruption of T-cell receptor (TCR) signaling with a defective function of T-cell responses. ${ }^{11}$

Here, we report that the combination of chronic CS exposure in the presence of a severe reduction of $\mathrm{T}$ cells results in the development of lung emphysema and goblet cell metaplasia. Reduced T-cell response in smoking mice results in chronic inflammation with the presence of a large number of neutrophils and activated macrophages.

These findings provide evidence that $\mathrm{T}$ lymphocytes play a trivial role in the development of smoking-induced lung emphysema and airway remodeling in smoking mice.

\section{Materials and Methods}

\section{Mice}

Wild-type (WT; C57 Bl/6J) and Lck-deficient $\left(L c k^{-1-}\right.$ with C57 Bl/6J background) mice were initially obtained from The Jackson Laboratory (Bar Harbor, ME). The colonies were expanded at Charles River' husbandries (Calco, Italy) and then supplied to Siena University animal house. The mice were housed in an environment controlled for light (7 $\mathrm{AM}$ to $7 \mathrm{PM}$ ) and temperature $\left(18^{\circ} \mathrm{C}\right.$ to $22^{\circ} \mathrm{C}$ ), and food (Mucedola Global Diet 2018; Harlan, Correzzana, Italy) and water were provided for consumption ad libitum. All animal experiments were conducted in conformity with the Guiding Principles for Research Involving Animals and Human Beings ${ }^{12}$ and were approved by the Local Ethics Committee of the University of Siena.

\section{Exposure to CS}

Male mice (at 6 to 8 weeks of age) from each experimental group were exposed to the smoke of three cigarettes/day, 5 days/week for 7 months (Virginia filter cigarettes, $12 \mathrm{mg}$ of tar and $0.9 \mathrm{mg}$ of nicotine) in especially designed cages, according to Cavarra et al. ${ }^{13}$ Control mice were exposed to air under the same conditions (sham-exposed). The concentration of smoke/air mixture was maintained at $140 \pm 12$ $\mathrm{mg} / \mathrm{m}^{3}$ total suspended particulate. Air-control and smoking mice were anesthetized with sodium pentobarbital and sacrificed by severing the abdominal aorta.

\section{Determination of Lymphocyte T Subsets by Fluorescence Activated Cell Sorter}

Peripheral blood was obtained by cardiac puncture with the use of heparin as anticoagulant and subjected to flow cytometry after hypotonic lysis of red blood cells. Fluorescein isothiocyanate-conjugated anti-CD4 monoclonal antibody (mAb) and phosphatidylethanolamine-conjugated anti-CD8 mAb (BD Biosciences, San Jose, CA) were used. Flow cytometry was performed on a GUAVA EasyCyte 6-2L flow cytometer (Millipore, Billerica, MA), and data were analyzed and plotted with the use of FlowJo software version n.6 (TreeStar Inc., Ashland, OR).

\section{Morphology, Morphometry, and Biochemistry}

At 7 months after CS exposure, the lungs of 8 of 10 mice from each group were fixed intratracheally with formalin (5\%) at a pressure of $20 \mathrm{~cm} \mathrm{H}_{2} \mathrm{O}$. Postfixation lung volume was measured by water displacement. The lungs of mice were then processed for histologic, morphometric, and immunohistochemical analyses. Lung slices were stained with hematoxylin and eosin, periodic acid-Schiff (PAS) stain, and Masson trichrome. Assessment of emphysema included mean linear intercept ${ }^{14}$ and internal surface area. ${ }^{15}$ The development of goblet cell metaplasia was evaluated by PAS reaction. ${ }^{16,17}$

Quantification of goblet cell metaplasia was performed on PAS-stained lung sections from five mice from each group. The number of $\mathrm{PAS}^{+}$cells in airways was determined by examining eight intrapulmonary airways per section and counting at least 3000 cells/section. Data were reported both as the number of positive cells per millimeter of basement membrane and as the percentage of positive cells per total cells.

Peribronchiolar fibrosis was quantitated in eight mouse lungs from each group. The sea-green area of peribronchial trichrome staining in paraffin-embedded lung was quantified under a light microscope by point counting with the use of a grid with 100 points, a $10 \times$ objective, and a computer screen for a final magnification of $\times 820$.

The sea-green area of the tissue section, $A$, was measured with point counting as follows: $\mathrm{A}=\Sigma \mathrm{P} \times \mathrm{a}$ (p), where $\Sigma \mathrm{P}$ is the number of points hitting tissue, and $\mathrm{a}(\mathrm{p})$ is the area associated with each point in the counting grid $\left[\mathrm{a}(\mathrm{p})=900 \mu \mathrm{m}^{2}\right]$.

Results are expressed as the area of trichrome staining per micrometer length of basement membrane of bronchioles 150 to $200 \mu \mathrm{m}$ of internal diameter.

Tissue slides were analyzed independently by three different observers. The slides were coded to prevent bias.

In addition five mice from each groups were used for elastin determination, assessed as desmosine according to a method previously described in detail. ${ }^{18}$ Similarly, additional samples taken from five lungs from each group and stored in liquid nitrogen $\left(\right.$ at $-80^{\circ} \mathrm{C}$ ) were used for mRNA expression of perforin, granzyme B, IL-6, monocyte chemoattractant protein $1, \mathrm{KC}$, and tumor necrosis factor- $\alpha$.

\section{Immunohistochemistry}

Tissue sections (5 $\mu \mathrm{m}$ thick) were pretreated with $3 \%$ hydrogen peroxide to inhibit the activity of the endogenous peroxidases. For antigen retrieval, the sections were heated in a microwave for 20 minutes in citrate buffer $0.01 \mathrm{mmol} / \mathrm{L}$, $\mathrm{pH}$ 6.0, and allowed to cool slowly to room temperature. The slides were then incubated with $3 \%$ bovine serum albumin for 30 minutes at room temperature to block nonspecific antibody binding and then were exposed to primary antibodies overnight at $4^{\circ} \mathrm{C}$. The following antibodies were used: rat monoclonal anti-mouse to CD45R/B220 (dilution 1:20; BD 
Pharmingen, Buccinasco, Italy), rat monoclonal anti-mouse to CD4 (dilution 1:1000; Abcam, Cambridge, UK), rabbit polyclonal $\mathrm{Ab}$ to myeloperoxidase (undiluted; Abcam), rat monoclonal anti-mouse MAC-3 (dilution 1:20; (BD Pharmingen), rabbit polyclonal $\mathrm{Ab}$ to mouse inducible nitric oxide synthase (iNOS; dilution 1:100; Abcam), and goat polyclonal $\mathrm{Ab}$ to mouse eosinophil chemotactic factor-L (Chitinase; dilution 1:250; R\&D Systems Europe, LTD, Abingdon, UK).

For CD4, CD45R/B220, and MAC-3 detection, the sections were rinsed and incubated with goat biotinylated polyclonal Ab anti-rat IgG (dilution 1:100; Abcam) for 30 minutes at room temperature. The staining was revealed by adding streptavidin-horseradish peroxidase (BD Pharmingen). Detection was accomplished by incubation in diaminobenzidine freshly dissolved in $0.03 \% \mathrm{H}_{2} \mathrm{O}_{2}$ in $50 \mathrm{mmol} / \mathrm{L}$ Tris/ $\mathrm{HCl}, \mathrm{pH}$ 7.6. As negative controls for the immunostaining, the primary $\mathrm{Ab}$ was replaced by nonimmunized rat serum.

For iNOS and myeloperoxidase detection, sections were rinsed and incubated with goat polyclonal $\mathrm{Ab}$ anti-rabbit IgG (dilution 1:200); for eosinophil chemotactic factor-L detection sections were rinsed and incubated with rabbit polyclonal Ab anti-goat IgG (dilution 1:50; Sigma-Aldrich, Indianapolis, IN). The staining was revealed by using the immunoperoxidase method. As negative controls for the immunostaining, the primary $\mathrm{Ab}$ was replaced by nonimmunized rabbit and goat serum.

The M.O.M. immunodetection kit (Vector Laboratories, Burlingame, CA) was used for immunodetection of mouse monoclonal $\mathrm{Ab}$ to $\mathrm{CD} 8-\alpha$ (dilution 1:100; Santa Cruz Biotechnology Inc., Heidelberg, Germany) and mouse monoclonal $\mathrm{Ab}$ to arginase I (dilution 1:100; BD Pharmingen). As negative controls for the immunostaining, the primary $\mathrm{Ab}$ was replaced by nonimmunized serum.

Volume fractions of the immunopositive cells were determined by point counting with the use of a grid with 48 points, a $20 \times$ objective. ${ }^{19}$ Twenty fields were examined for each pair of lungs for a total of 960 points. The number of points that fell on stained cells was divided by the total number of points on the lung section. This number was then multiplied by the volume of the lung corrected by the weight of the mouse to give the total volume of the specifically stained cells in the lung. ${ }^{20}$

The number of mice was eight in all groups.

\section{RNA Isolation and cDNA Synthesis}

Total RNA was extracted from lungs of mice at 7 months after chronic exposure to room air or CS, using TRi Reagent (Ambion, Austin, TX) according to the manufacturer's instructions. Five mice for each group were used for RNA isolation. RNA was resuspended in RT-PCR Grade Water (Ambion), and the amount and purity of RNA were quantified spectrophotometrically by measuring the optical density at 260 and $280 \mathrm{~nm}$. Integrity was checked by agarose gel electrophoresis.
Table 1 Primers and Probes Used for Real-Time PCR

\begin{tabular}{|c|c|c|c|}
\hline $\begin{array}{l}\text { Gene name } \\
\text { (protein } \\
\text { name) }\end{array}$ & Primers & $\begin{array}{l}\text { Amplicon } \\
\text { length } \\
\text { (nt) }\end{array}$ & $\begin{array}{l}\text { UPL } \\
\text { probe }\end{array}$ \\
\hline Il6 & $\begin{array}{l}\text { F 5'-TGCCTTCATTTATCCCTTGAA-3' } \\
\text { R 5 5'-TTACTACATTCAGCCAAAAAGCAC-3' }\end{array}$ & 63 & \#93 \\
\hline Mcp1 & $\begin{array}{l}\text { F 5'-CATCCACGTGTTGGCTCA-3' } \\
\text { R 5 5'-GATCATCTTGCTGGTGAATGAGT-3' }\end{array}$ & 76 & $\# 62$ \\
\hline$K c$ & $\begin{array}{l}\text { F } 5^{\prime}-\text { TGCTCAAGGCTGGTCCAT-3' } \\
\text { R 5 5'-GACATCGTAGCTCTTGAGTGTCA-3' }\end{array}$ & 86 & $\# 18$ \\
\hline Tnfa & $\begin{array}{l}\text { F 5'-CTGTAGCCCACGTCGTAGC-3' } \\
\text { R 5 5'-TTGAGATCCATGCCGTTG-3' }\end{array}$ & 97 & $\# 25$ \\
\hline $\begin{array}{l}\text { Pfn } \\
\text { (Perforin) }\end{array}$ & $\begin{array}{l}\text { F } 5^{\prime} \text {-GAAGAAGAAACAGCACAAAATGG-3' } \\
\text { R } 5^{\prime} \text {-GACGTGACGCTCACGGTAG-3' }\end{array}$ & 61 & \#31 \\
\hline Gzmb & $\begin{array}{l}\text { F 5'-GCTGCTCACTGTGAAGGAAGT-3' } \\
\text { R 5'-TGGGGAATGCATTTTACCAT-3' }\end{array}$ & 107 & $\# 2$ \\
\hline
\end{tabular}

F, forward; $R$, reverse; UPL, Universal ProbeLibrary.

Two micrograms of total RNA was treated with TURBO DNase (TURBO DNA-free kit; Ambion) for 30 minutes and reverse transcribed with the RETROscript kit (Ambion) according to the manufacturer's instructions. Two hundredths of the final volume of reverse transcription was used for real-time RT-PCR.

\section{Real-Time RT-PCR}

Real-time RT-PCR was performed in triplicate for each sample on the MJ Opticon Monitor 2 (MJ Research Co., Waltham, MA) with specific locked nucleic acid probes from the Mouse Universal ProbeLibrary Set (Roche, Indianapolis, IN).

Primers were designed by using the free online ProbeFinder software (available at the Universal ProbeLibrary Assay Design Center, www.universalprobelibrary.com, last accessed February 24, 2016) that shows a pair of specific primers for each probe from the Universal ProbeLibrary set (Table 1). PCR reactions were performed in a volume of $25 \mu \mathrm{L}$ and contained $12.5 \mu \mathrm{L}$ of FastStart TaqMan Probe Master (Roche), $300 \mathrm{nmol} / \mathrm{L}$ forward and reverse primers (TIBMolbiol, Genova, Italy), $200 \mathrm{nmol} / \mathrm{L}$ Universal ProbeLibrary probes, and $5 \mu \mathrm{L}$ of cDNA. Reactions were incubated at $95^{\circ} \mathrm{C}$ for 10 minutes and then amplified for 40 cycles, each cycle comprised of an incubation step at $94^{\circ} \mathrm{C}$ for 15 seconds, followed by $60^{\circ} \mathrm{C}$ for 1 minute. The real-time RT-PCR assay included a notemplate control and a standard curve of four serial dilution points (in steps of 10-fold) of each of the test cDNAs. The analysis of the results was based on the comparative cycle threshold method $(\Delta \Delta \mathrm{Ct})$ in which $\mathrm{Ct}$ represents the cycle number at which the fluorescent signal, associated with an exponential increase in PCR products, crosses a given threshold. The average of the target gene was normalized to $18 \mathrm{~S}$ rRNA as the endogenous housekeeping gene. ${ }^{21}$ The combination of primers and probes provides specific amplification and detection of the target sequence in the sample. 
A

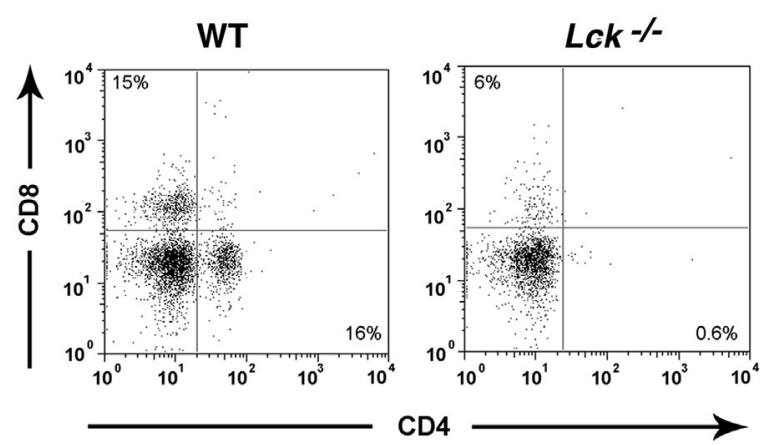

B

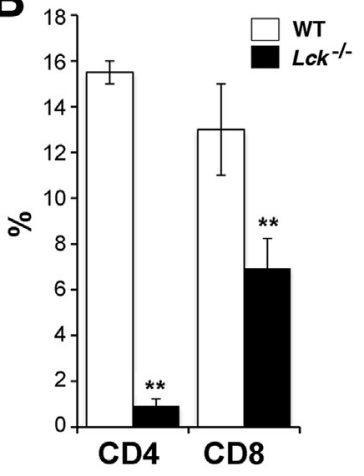

Figure 1 Flow cytometric analysis of lymphocytes from peripheral blood of WT or $L \mathrm{LK}^{-/-}$mice stained with the indicated surface markers. A: Representative fluorescence activated cell sorter profile of CD4/CD8 labeling of peripheral blood from WT or $\mathrm{LCk}^{-/-}$mice. B: Bar graphs showing the percentage of $\mathrm{CD}^{+}$or $\mathrm{CD}^{+}$cells in peripheral blood from WT or $\mathrm{LCk}^{-/}$mice. For each sample, fluorescence was analyzed on gated cells with forward and side light scatter properties of lymphocytes. Data are expressed as means \pm SD. $n \geq 2$ WT control and $5 \mathrm{Lck}^{-/-}$mice. ${ }^{* *} P<0.01 \mathrm{Lck}^{-/-}$ versus WT mice. WT, wild-type.

\section{Statistical Analysis}

Data are expressed as means $\pm \mathrm{SD}$. The significance of the differences was calculated with one-way analysis of variance. A $P$ value of $<0.05$ was considered significant.

\section{Results}

To assess the role of $\mathrm{T}$ cells in the development of smokinginduced lung emphysema and airways remodeling, mice with a severe reduction of peripheral T cells, namely $L c k^{-l-}$ mice, were used. As previously reported ${ }^{10} L c k^{-l-}$ mice developed a profound thymic atrophy that resulted in a dramatic reduction of double positive $\left(\mathrm{CD} 4^{+} \mathrm{CD} 8^{+}\right)$thymocytes and in peripheral $\mathrm{T}$ cells (Figure 1).

The lungs of the mice from WT and $L c k^{-l-}$ groups exposed to room air for 7 months showed a well-fixed normal parenchyma with normal airways and were virtually indistinguishable from each other (Figure 2, A and B). The lungs of mice from both genotypes exposed for 7 months to CS showed foci of emphysema disseminated throughout the lung parenchyma (Figure 2, C and D). In both phenotypes after CS exposure, the inflammation was particularly evident in some fields and was characterized by a moderate amount of polymorphonuclear and mononuclear cell infiltrates in perivascular areas (Figure $3 \mathrm{~A}, \mathrm{~B}, \mathrm{E}$, and F) and in peribronchiolar spaces (Figure $3 \mathrm{C}, \mathrm{D}, \mathrm{G}$ and $\mathrm{H}$ ). Neutrophils and macrophages were observed throughout the lung parenchyma and increased in both genotypes by approximately $120 \%$ (116\% in WT; $127 \%$ in $\mathrm{Lck}^{-l-}$ mice; $P<0.01)$ and by approximately $125 \%(128 \%$ in WT; $123 \%$ in $L c k^{-l-}$ mice; $P<0.01$ ), respectively (Figure 3, I and $\mathrm{J}$ ). Sparse and isolated $\mathrm{T}$ and $\mathrm{B}$ cells could be found in peribronchial structure of WT mice after CS exposure (Supplemental Figure S1, C, G, and K). Few T or B cells, sparse or organized in lymphoid follicles, could be seen in lung slices of smoking $L c k^{-l-}$ mice (Supplemental Figure S1,
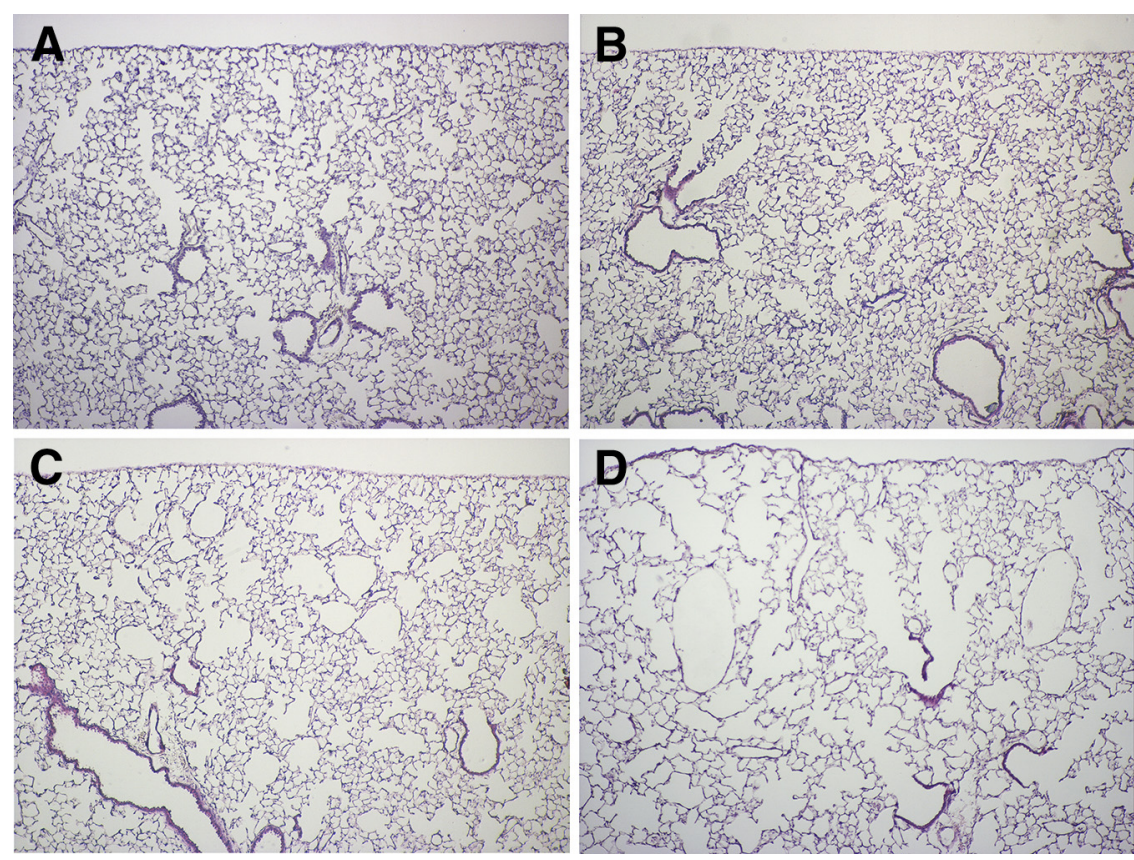

Figure 2 Lung morphology. Representative histologic sections from lungs of mice at 7 months after air or CS exposure. A: WT mouse exposed to air with a normal parenchyma. B: $\mathrm{LCK}^{-/}$mouse exposed to air with a normal parenchyma. C: WT mouse showing after CS disseminated foci of emphysema. D: $\mathrm{LCK}^{-/-}$mouse showing after CS evident areas of emphysema. Hematoxylin and eosin staining. Scale bar $=120 \mu \mathrm{m}$. CS, cigarette smoke; WT, wild-type. 

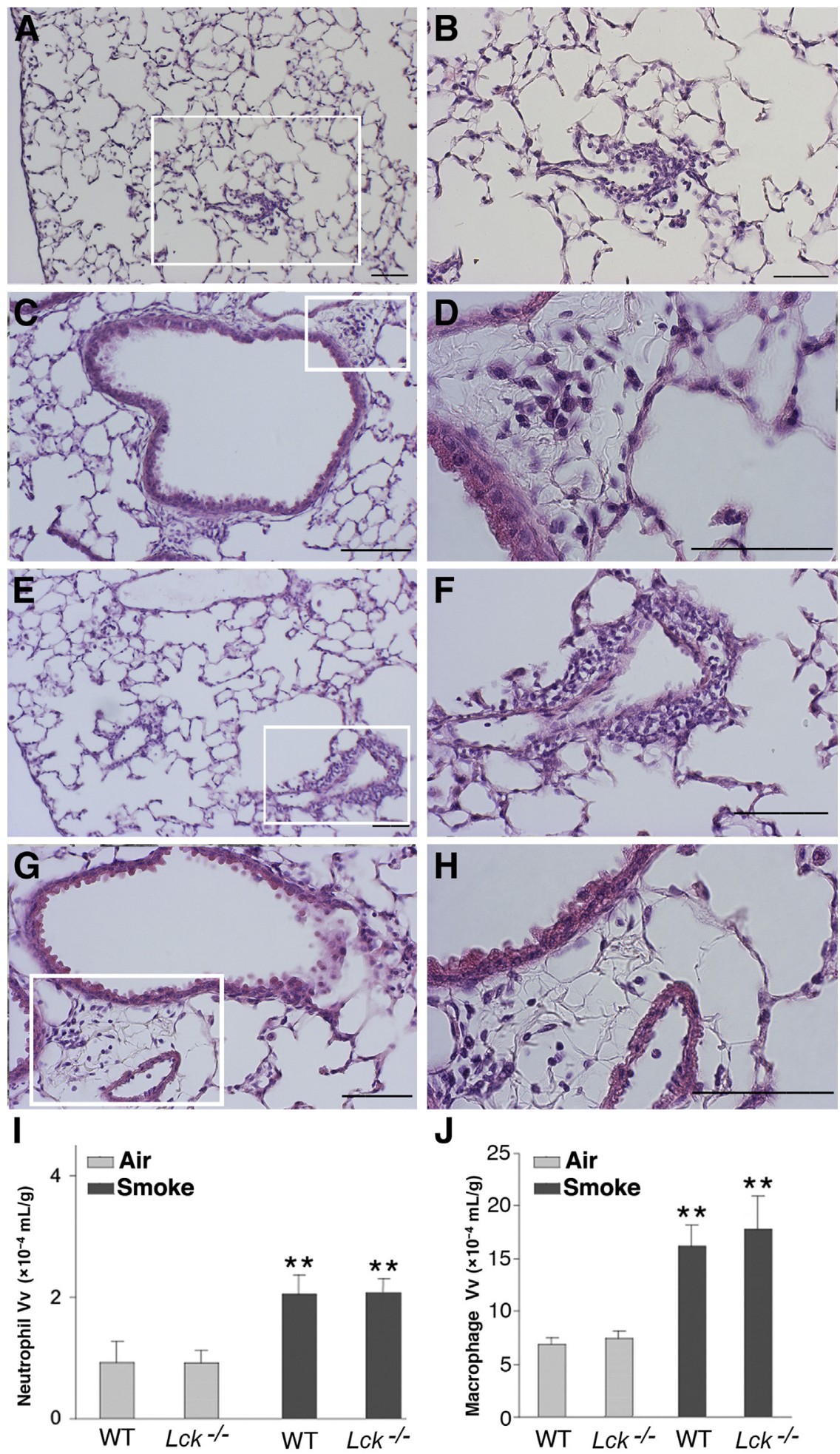

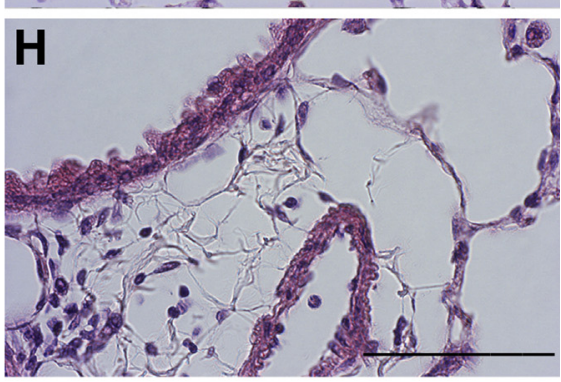

J

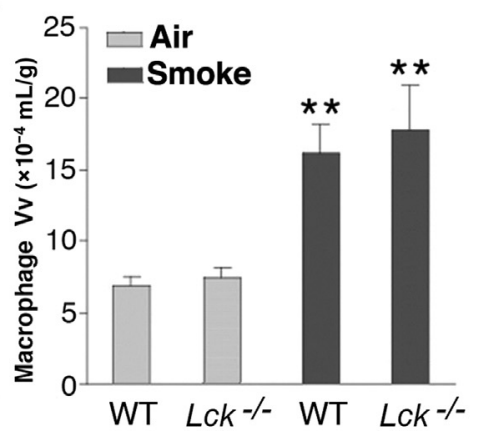

Figure 3 Inflammatory cells in the lung of smoking WT and $\mathrm{LCK}^{-/-}$mice. Representative histologic lung sections from $\mathrm{Lck}^{-/-}(\mathbf{A}-\mathbf{D})$ and WT (E and $\mathbf{F}$ ) mice at 7 months after CS exposure. A: Perivascular infiltrate of inflammatory cells in a lung slide from a smoking $\mathrm{Lck}^{-1-}$ mouse. C: Peribronchiolar infiltrates of polymorphonuclear and mononuclear cells in a lung slide from a smoking $\mathrm{LCK}^{-/-}$mouse. B and D: Represent higher magnification of areas delineated in white squares in panels $\mathbf{A}$ and $\mathbf{C}$, respectively. Perivascular $(\mathbf{E})$ and peribronchiolar (G) inflammatory cell infiltrates in the lung slides from smoking WT mice. $\mathbf{F}$ and $\mathbf{H}$ : Represent higher magnification of areas delineated in white squares in panels $\mathbf{E}$ and $\mathbf{G}$, respectively. Hematoxylin and eosin staining. I: Neutrophil volume density in the lung of WT or $\mathrm{Lck}^{-/-}$mice exposed either to room air or to CS for 7 months after immunohistochemical reaction for myeloperoxidase. J: Macrophage volume density in the lung of WT and or $\mathrm{LCK}^{-/-}$mice exposed either to room air or to CS for 7 months performed after immunohistochemical reaction for macrophage Mac-3. Data are presented as means \pm SD. $n=8$ mice in all groups. ${ }^{* *} P<0.01$ versus respective air-exposed controls. Scale bar $=120 \mu \mathrm{m}$. Air, air exposure; CS, cigarette smoke; KO, knockout; Smoke, CS-exposure; WT, wild-type.
$\mathrm{D}, \mathrm{H}$, and $\mathrm{L}$ ). A small number of $\mathrm{CD}^{+}$and $\mathrm{CD} 8^{+} \mathrm{T}$ cells and $\mathrm{B}$ cells were found in lung slices from air-control mice of both genotypes (Supplemental Figure S1, A, B, E, F, I, and $\mathrm{J}$ ). Volume fractions of $\mathrm{T}$ and $\mathrm{B}$ immunopositive cells determined by point counting in lungs from control and smoking mice of the different substrains are reported in Figure 4, A-C. Tertiary lymphoid structures, containing germinal centers, were not present in lung parenchyma of airexposed and CS-exposed WT or $L c k^{-1-}$ mice.

Morphometric evaluation of lung parenchyma confirmed that mice from both genotypes showed the same degree of emphysematous lesions as revealed by mean linear intercepts and internal surface area examination (Table 2). In particular, chronic exposure to CS resulted in $L c k^{-1-}$ mice 
A

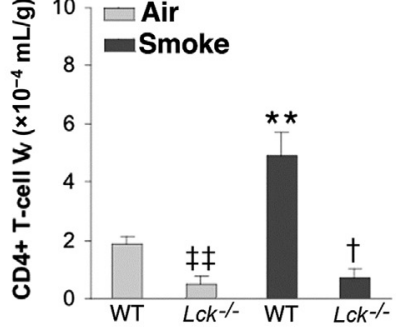

D

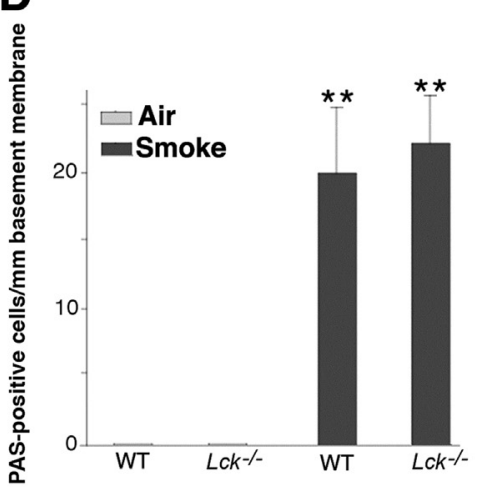

$\mathbf{F}$

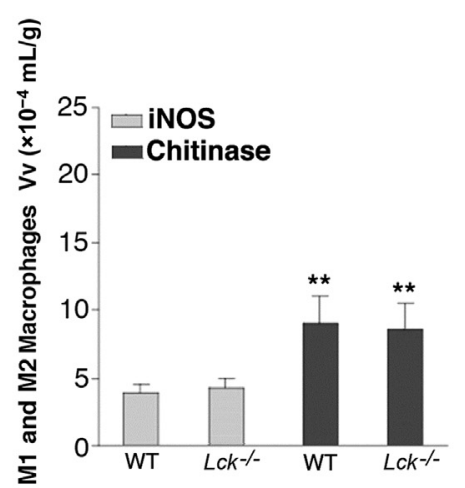

B

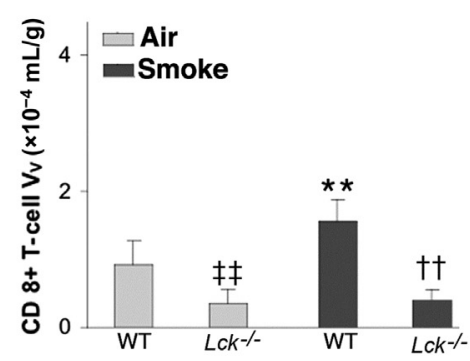

E

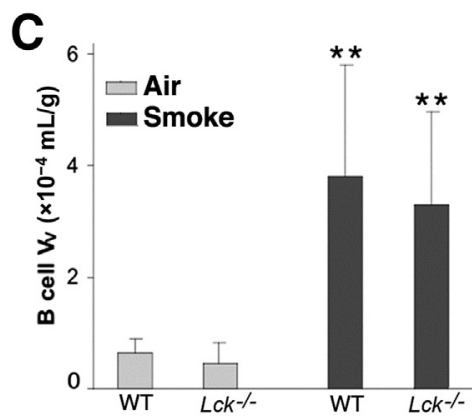

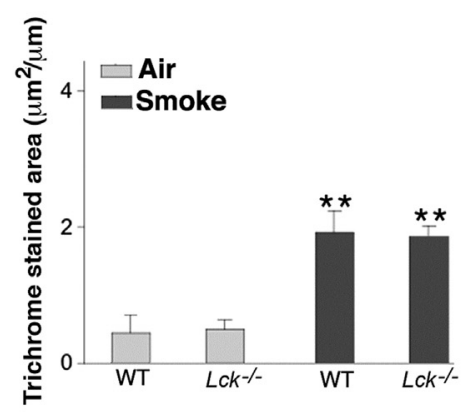

G

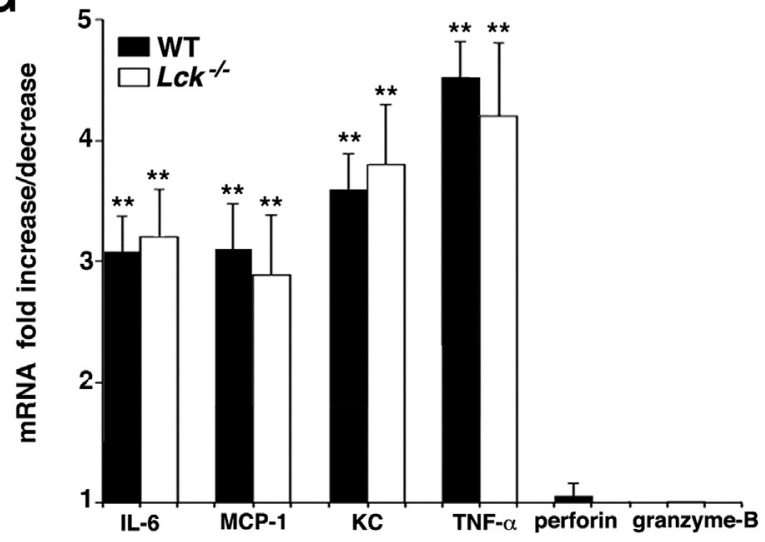

Figure 4 A: Volume density of $\mathrm{CD}^{+} \mathrm{T}$ cells in the lung of WT and $L c k^{-/-}$mice exposed either to room air or to CS for 7 months. B: $C D 8^{+} \mathrm{T}-\mathrm{cell}$ volume density in the lung of WT and $\mathrm{LCk}^{-/-}$mice exposed either to room air or to CS for 7 months. C: B-cell volume density in the lung of WT and $L c k^{-1-}$ mice exposed either to room air or CS for 7 months. D: Quantitation of PAS ${ }^{+}$cells in airways from WT and $\mathrm{Lck}^{-1-}$ mice exposed either to room air or to CS for 7 months. The number of cells per millimeter of basement membrane was determined. E: Trichrome-stained area. The analysis was performed on bronchioles 150 to $200 \mu \mathrm{m}$ of internal diameter. F: Volume density of $\mathrm{iNOS}^{+}$(M1) and Chitinase ${ }^{+}$(M2) macrophages in the lung of WT and $\mathrm{Lck}^{-/-}$mice exposed either to room air or to CS for 7 months. G: Real-time PCR analysis of mRNAs for IL-6, MCP-1, KC, TNF- $\alpha$, perforin, and granzyme B performed on lungs from mice from each experimental group at 7 months after CS exposure. Values are corrected for $18 S$ rRNA and normalized to a median control value of 1.0. Data are presented as means \pm SD and as values of sea-green area per micrometer length of basement membrane (E). $n=8$ mice in all groups $(\mathbf{A}-\mathbf{D}$ and $\mathbf{F}) ; n=8$ intrapulmonary airway/sections (D); $n=5$ mice in each experimental group (E and $\mathbf{G}) .{ }^{* *} P<0.01$ versus respective air-exposed mice $(\mathbf{A}, \mathbf{B}, \mathbf{D}$, and $\mathbf{E}) ;{ }^{* *} P<0.01$ versus air-exposed mice of the same genotype (C and $\mathbf{F}) ;{ }^{* *} P<0.01$ compared with the median control value of $1.0(\mathbf{G}) .{ }^{\dagger} P<0.05$ versus smoke-exposed WT mice $(\mathbf{A})$; ${ }^{\dagger \dagger} P<0.01$ versus smoke-exposed WT mice (B); ${ }^{\ddagger \ddagger} P<0.01$ versus air-exposed WT mice (A and $\left.\mathbf{B}\right)$. Air, air exposure; CS, cigarette smoke; iNOS, inducible nitric oxide synthase; K0, knockout; MCP-1, monocyte chemotactic protein 1; PAS, periodic acid-Schiff; Smoke, CS exposure; TNF, tumor necrosis factor; WT, wild-type.

in a significant increase of mean linear intercept values $(15 \% ; P<0.01)$ and in a significant decrease of internal surface area values $(-16 \% ; P<0.01)$. Similar results were obtained in smoking WT mice. The results of the biochemical analysis of lung desmosine content, expressed as micrograms per lung, are also shown in Table 2. In mice from both genotypes chronically exposed to CS, lung levels of desmosine were significantly lower than those of airexposed controls $(P<0.01)$.

CS exposure for 7 months induced in WT and $L c k^{-1-}$ mice the development of goblet cell metaplasia within the epithelium of large- and middle-sized bronchi, as evident 
Table 2 Lung Morphometry and Elastin (Determined as Desmosine) after Chronic Cigarette Smoke Exposure

\begin{tabular}{|c|c|c|c|c|c|c|}
\hline \multirow[b]{2}{*}{ Exposure } & \multicolumn{2}{|l|}{$\operatorname{Lm}(\mu \mathrm{m})$} & \multicolumn{2}{|l|}{ ISA $\left(\mathrm{cm}^{2}\right)$} & \multicolumn{2}{|c|}{ Desmosine ( $\mu \mathrm{g} / \mathrm{lung})$} \\
\hline & WT & $L c k^{-/-}$ & $\overline{W T}$ & $L c k^{-/-}$ & $\overline{W T}$ & $L c k^{-/-}$ \\
\hline Air & $39.7 \pm 0.7$ & $41.20 \pm 0.7$ & $1212 \pm 72$ & $1170 \pm 67$ & $2.9 \pm 0.12$ & $2.86 \pm 0.12$ \\
\hline
\end{tabular}

Data are presented as means \pm SD. $n=8$ and 5 mice for each group were used for morphometric and desmosine analysis, respectively.

${ }^{*} P<0.01$ versus air-control mice of the same strain.

ISA, internal surface area of lungs; Lm, mean linear intercept; WT, wild-type.

after PAS staining (Supplemental Figure S2, B and D). It is well known that mice do not have goblet cells in their bronchi (Supplemental Figure S2, A and C); thus, they are considered to have goblet cell metaplasia when at least one or more middle-sized bronchi/lung showed a positive PAS staining. ${ }^{16}$ Quantification of goblet cell metaplasia in the different experimental groups is reported in Figure 4D, no difference was observed between both genotypes chronically exposed to CS.

Bronchial or peribronchiolar regions showed an increased collagen deposition (sea-green stain) in smoking WT and $L c k^{-1-}$ mice (Supplemental Figure S2, F and H). In some areas from both genotypes an evident fibrotic reaction was seen (Supplemental Figure S2H). Only a small amount of collagen was found around bronchioles and distal bronchi of air-control mice of both substrains (Supplemental Figure S2, $\mathrm{E}$ and $\mathrm{G})$. The quantification of sea-green areas performed by point counting did not reveal a difference between the two strains of mice at 7 months after CS exposure (Figure 4E).

Only few macrophages from air-exposed mice showed a faint reaction for iNOS and Chitinase in lung slides from air-exposed mice. The immunohistochemical reaction for iNOS and Chitinase are reported in lung slides from airexposed $\mathrm{Lck}^{-/-}$(Supplemental Figure S3, A and B, respectively) and from WT mice (Supplemental Figure S3, $\mathrm{C}$ and $\mathrm{D}$, respectively).

WT mice exposed to CS showed in peripheral areas of the lung a prevalence of $\mathrm{M} 1$ polarized macrophages, as detected by immunohistochemical method for iNOS (Supplemental Figure S3G). This immunoreaction was virtually absent in air control WT mice (Supplemental Figure S3C). In the same strain, macrophages with a prevalent M2 pattern of activation were found after CS around bronchioles and segmental bronchi as detected by a strong reaction for Chitinase (Supplemental Figure S3H). Similar findings were observed for Arginase 1 (data not shown).

A distribution and polarization similar to those observed in WT mice were found in pulmonary macrophages of smoking $L c k^{-/-}$mice (Supplemental Figure S3, E and F). Volume fractions of M1 and M2 polarized macrophages determined by point counting in lungs from smoking mice of the different substrains are reported in Figure 4F.

The lung changes we observed in smoking mice at 7 months after CS exposure were accompanied by a significant increase of several proinflammatory cytokines such as IL-6, monocyte chemoattractant protein $1, \mathrm{KC}$, and tumor necrosis factor- $\alpha$. However, no significant difference was found between the two genotypes (Figure 4G). No difference among the various experimental groups was found in the expression levels of perforin and granzyme B, the two major cytolytic effector proteins of natural killer $(\mathrm{NK})$ and CD8 T cells (Figure 4G).

\section{Discussion}

We report here that mice with a severe reduction of the number of peripheral $\mathrm{T}$ cells and with a defective cell function because of a targeted mutation of the $L c k$ gene $e^{10,11}$ after chronic CS exposure develop emphysema and airways changes similar to those observed in WT mice. ${ }^{13,16,17}$

Although COPD has been the subject of extensive investigation over the past decades, the mechanisms involved in the pathogenesis of the disease are still the subject of debate. These include protease/antiprotease and oxidant/antioxidant imbalances, increased rate of epithelial cell apoptosis, and abnormal innate or adaptive immune responses. ${ }^{22,23} \mathrm{CS}$ is the most important risk factor for the development of COPD, and there are numerous reports on increased oxidative stress and increased lung protease burden in smokers and in patients with COPD. ${ }^{24-26}$ Several mechanisms were postulated as to how proteases and/or oxidants can cause lung dysfunction. ${ }^{22-26}$ Protease/antiprotease and oxidant/antioxidant imbalances may originate from innate and adaptive immune responses of which many elements are abnormal in COPD. Although the innate immune response has long been considered important in the pathogenesis of COPD, reports have underlined a potential role for $\mathrm{T}$ lymphocytes in the inflammatory process that leads to COPD. ${ }^{6,27,28}$

\section{Role for T Cells in Inducing Emphysema and Bronchial/} Bronchiolar Lesions after CS Exposure

An increased number of CD8 $\mathrm{T}$ cells with a potential harmful capacity can be found in lungs of COPD patients ${ }^{29-31}$ and mice chronically exposed to $\mathrm{CS}^{32}$ On this basis, it was assumed that an increase in the proinflammatory and cytotoxic activity of CD8 $\mathrm{T}$ cells might represent a key mechanism by which these cells contribute to the pathophysiology of COPD. ${ }^{4,5}$ It was hypothesized that CS induces activation of CD8 $\mathrm{T}$ cells, leading to production of interferon- $\gamma-$ inducible proteins that were shown 
to induce macrophage production of matrix metalloprotease$12 .{ }^{33}$ Such a metalloprotease can degrade elastin, giving rise to airspace enlargement. ${ }^{34}$

CD8 cells play an important role in autoimmune diseases such as rheumatoid arthritis, systemic lupus erythematosus, and diabetes mellitus. ${ }^{35}$ Autoreactive CD8 cells can drive autoimmunity through cytotoxic activity that leads to tissue destruction. $^{36}$

Unfortunately, no direct or indirect evidence is available in the literature to define COPD as an autoimmune disease and at the current time, this hypothesis (the autoimmune cause of COPD) is supported only by circumstantial evidence because it is based only on the presence of infiltrating mononuclear cells in the affected organ or tissue. ${ }^{37}$

Actually, no evidence can be found in literature to recognize a direct role for $\mathrm{T}$ cells in inducing emphysema and bronchial/bronchiolar lesions either by proteolysis or by induction of apoptosis. Further support for such a view derives from the results on perforin and granzyme B expression that we present in the current study. In a recent study Eppert et $\mathrm{al}^{38}$ reported that neither CD4 nor CD8 T-cell transfer from donor mice exposed to CS are alone sufficient to cause inflammation or pathologic characteristics to CS-naive immunosufficient mice. In addition, recipient mice deficient in major histocompatibility complex (MHC) class I are protected from lung damage and inflammation caused by $\mathrm{T}$ cells transferred from CSexposed mice. This study defines the requirement for both CD4 and CD8 T cells from CS-exposed donor mice and antigen presentation to $\mathrm{CD} 8 \mathrm{~T}$ cells on MHC class I molecules for transfer of airspace enlargements and inflammation. ${ }^{38}$ Unfortunately, the antigen(s) responsible for the generation of autoreactive $T$ cells in patients with COPD and mouse models of COPD remain undefined.

\section{Reduction in Number and Function of T Cells Does Not Confer Protection from CS-Induced Pulmonary Changes}

The findings reported in our study are in agreement with those reported by D'Hulst et al ${ }^{39}$ to indicate that Scid mice are not protected from CS-induced emphysema and that adaptive immune system is not required per se to induce pulmonary emphysema after CS exposure. In $L c k^{-/-}$mice, no biological relevant functions of $T$ cells can be detected because the reduced peripheral $\mathrm{T}$ cells present in these mice are unable to respond to TCR-Ag-MHC activation. ${ }^{11}$ However, we cannot exclude that $\mathrm{T}$ cells in smoking $L c k^{-l-}$ mice are able to produce proinflammatory cytokines also in the absence of TCR ligation.

Motz et $\mathrm{al}^{28}$ transferred $\mathrm{CD}^{+} \mathrm{T}$ cells purified from the lungs of smoking mice into recipient mice knocked out for $\operatorname{Rag} 2\left(\operatorname{Rag} 2^{--}\right)$, a gene involved in the initiation of V(D)J recombination during B- and T-cell development. After 13 weeks of exposure to CS or filtered air, the recipient Rag $2^{-/-}$ mice showed generation of pathogenic $\mathrm{T}$ cells that persistently produce proinflammatory cytokines in the absence of antigen-dependent T-cell stimulation. These findings are in agreement with the data reported in our study whose experimental design (that includes specific methods to assess COPD lesions) and findings complement that of Motz et al. ${ }^{28}$ These studies all together suggest that CD8 $\mathrm{T}$ cells may contribute per se by means of antigen-independent mechanism(s) to the onset and progression of COPD in patients by production of proinflammatory cytokines ${ }^{28}$ that recruit additional cell types to the inflamed tissue. An antigenindependent activation of $\mathrm{T}$ cells may explain why the results we found in smoking $L c k^{-1-}$ mice in terms of inflammation (increase in number of tissue neutrophils and macrophages, increase in proinflammatory cytokine expression) and tissue destruction (positivity of morphometric end points for COPD), are different from those reported by Maeno et $\mathrm{al}^{6}$ in smoking $\mathrm{CD} 8^{-1-}$ mice characterized by a complete absence of CD8 T cells. The occurrence of a population of antigen-independent stimulated $\mathrm{T}$ cells may explain also why our results in $L c k^{-1-}$ mice after CS are similar to those observed by Motz et $\mathrm{al}^{28}$ in WT and Rag $2^{-1-}$ mice.

Our results are also in agreement with the observation of D'Hulst et al ${ }^{39}$ that Scid mice develop inflammation and emphysema after chronic CS exposure. The occurrence of leakiness in Scid mice, which leads to the production of some functional B and T cells may explain the CS-induced emphysema in the study of D'Hulst et al. ${ }^{39}$ Another explanation may be related to the presence of destructive NK cells. However, no evidence for such a view is available at the levels of perforin and granzyme B, the two major cytolytic effector proteins of $\mathrm{T}$ cells and NK cells that did not increase in the study of D'Hulst et $\mathrm{al}^{39}$ and in our study. Moreover, no increased number of NK cells could be found after CS exposure in smoking mice. ${ }^{40}$ These data all together exclude a role for NK cells in inducing emphysema and bronchial/bronchiolar lesions by perforin/granzyme pathway.

Our data further support the conclusion reported by Motz et $\mathrm{al}^{28}$ that CS can generate pathogenic CD8 T cells capable of enhancing monocyte/macrophage and neutrophil accumulation, inducing activation of proteases, and thus contributing to degradation of extracellular matrix. The absence of CD8 $\mathrm{T}$ cells in the lung of smoking mice may offer an explanation as to why the results reported by Maeno et $\mathrm{al}^{6}$ in terms of inflammation differ so markedly from those reported in the current study and in the study by Motz et al. ${ }^{28}$

\section{Potential Role of Lymphocytes in Exacerbations}

However, we cannot exclude that CD8 T cells in COPD may play an important role in microbial exacerbations by regulating macrophage accumulation and activation by antigen-dependent mechanism(s). The presence of infiltrating $\mathrm{T}$ or B lymphocytes ${ }^{41-43}$ reported in lungs of some patients with COPD may be related to pulmonary infections which are not directly linked to the onset of the disease but 
to its progression. In this context, the marked abnormal lung microbiome of some patients with advanced COPD likely drives symptoms and contributes to exacerbation severity and, thereby, mortality. ${ }^{41}$ Similarly in smoking models, the increased number of $\mathrm{T}$ and $\mathrm{B}$ cells in lungs may be related to concomitant infections when animals are maintained for a long time in conventional manner (and not in barriermaintained environments). ${ }^{19}$ Actually, the role of CD8 cells in exacerbations is a matter of debate. A recent study that dealt with immunoproteasome function in COPD shows that its expression and activity are directly altered by CS in vitro, in COPD patients, and in smoking mice. This results in disturbed MHC I antigen presentation and reduced T-cell activation. ${ }^{44}$ In addition, it was recently found that TCR components are down-regulated in pulmonary CD8 cells from COPD patients. ${ }^{45}$

\section{Smoking $\mathrm{LCK}^{-/-}$Mice Develop Chronic Lung Inflammation}

In conclusion, the findings reported in the current study indicate that $L c k^{-1-}$ mice exposed for 7 months to CS develop a chronic inflammation and lung and airways changes undistinguishable to those observed in WT mice under the same experimental conditions. A reduced T-cell antigen response in $L c k^{-1-}$ mice is associated with an innate immune response characterized by the accumulation of inflammatory cells, predominantly in the form of neutrophils and macrophages. Macrophage and neutrophil inflammation results in the development of elastolytic emphysematous lesions associated with consistent areas of goblet cell metaplasia in bronchial and bronchiolar epithelium. In addition, in the absence of a consistent T-cell response, pulmonary macrophages of smoking $L c k^{-/-}$mice showed within the lung parenchyma a prevalent M1 pattern of activation and a high destructive potential. ${ }^{46}$ However, pulmonary macrophages that are alternatively activated (M2) are present in peribronchial and peribronchiolar areas. The expression of Chitinase (and arginase) activity allows these cells to participate in wound healing and scarring. The different macrophage polarization that we observed in the different anatomical regions may explain why emphysema in smoking $L c k^{-/-}$mice is associated with a mild or moderate fibrotic reaction in some bronchial or peribronchiolar areas.

These two different histopathologic features, namely emphysema and airways remodeling, were also observed in smoking WT mice. These changes may be regarded as two different pathologic entities that resemble those observed in pulmonary tissue from patients with COPD.

In our opinion, the neutrophil and macrophage accumulation we observed in smoking mice from both genotypes cannot be related to the occurrence of lung infections. In fact, we did not observe an increase of neutrophils and macrophages in lungs of air-exposed mice, which were treated in the same fashion, in the same exposure chambers, and housed in the same environment and in the same conditions of CS-exposed mice.

Generally, in infected mice lymphoid neogenesis occurs and results in the formation of tertiary lymphoid structures in lung parenchyma. ${ }^{41}$ Such lymphoid follicles that contain germinal centers are not present in air-exposed and CSexposed WT or $L c k^{-1-}$ mice, in which there is no alteration in B-cell expansion and activation.

\section{Conclusions}

Collectively, our data indicate that targeted deletion of $L c k$ that leads to peripheral $\mathrm{T}$ cells unable to respond to TCR$\mathrm{Ag}-\mathrm{MHC}$ activation and to a reduction in their number ${ }^{10}$ does not confer protection against the development of emphysema and bronchial/bronchiolar remodeling induced in mice by CS exposure.

Actually, studies in our and other laboratories strongly suggest that innate inflammatory cells activated by different stimuli on surface cell receptors are required to develop pulmonary emphysema and airway remodeling in mice chronically exposed to $\mathrm{CS} .{ }^{47-52}$

However, the targeted deletion of $L c k$ in mice does not influence the expansion, maturation, and activation of $\mathrm{B}$ cells. These cells are increased in lungs of smoking WT and $L c k^{-1-}$ mice under our experimental conditions. For these reasons we cannot exclude a role, if any, in contributing to the degree of lung changes in our model. Although the findings reported by D'Hulst et al ${ }^{39}$ in smoking Scid mice do not support a role for B cells in inducing emphysema, recent data support a novel and convincing hypothesis that a dysregulation of $\mathrm{B}$ cells contributes to COPD progression that follows microbiome alteration. ${ }^{41-43}$

\section{Supplemental Data}

Supplemental material for this article can be found at http://dx.doi.org/10.1016/j.ajpath.2016.03.002.

\section{References}

1. Cigarette smoking and health. American Thoracic Society. Am J Respir Crit Care Med 1996, 153:861-865

2. Fletcher C, Peto R: The natural history of chronic airflow obstruction Br Med J 1977, 1:1645-1648

3. Tuder RM, Petrache I: Pathogenesis of chronic obstructive pulmonary disease. J Clin Invest 2012, 122:2749-2755

4. Cosio MG, Guerassimov A: Chronic obstructive pulmonary disease. Inflammation of small airways and lung parenchyma. Am J Respir Crit Care Med 1999, 160:S21-S25

5. Saetta M, Turato G, Maestrelli P, Mapp CE, Fabbri LM: Cellular and structural bases of chronic obstructive pulmonary disease. Am J Respir Crit Care Med 2001, 163:1304-1309

6. Maeno T, Houghton AM, Quintero PA, Grumelli S, Owen CA, Shapiro SD: $\mathrm{CD} 8+\mathrm{T}$ cells are required for inflammation and destruction in cigarette smoke-induced emphysema in mice. J Immunol 2007, 178:8090-8096 
7. Anderson SJ, Perlmutter RM: A signaling pathway governing early thymocyte maturation. Immunol Today 1995, 16:99-105

8. Levelt CN, Mombaerts P, Wang B, Kohler H, Tonegawa S, Eichmann K, Terhorst C: Regulation of thymocyte development through CD3: functional dissociation between p56lck and CD3 sigma in early thymic selection. Immunity 1995, 3:215-222

9. Levin SD, Anderson SJ, Forbush KA, Perlmutter RM: A dominantnegative transgene defines a role for p561ck in thymopoiesis. EMBO J 1993, 12:1671-1680

10. Molina TJ, Kishihara K, Siderovski DP, van Ewijk W, Narendran A, Timms E, Wakeham A, Paige CJ, Hartmann KU, Veillette A, Davidson D, Mak TW: Profound block in thymocyte development in mice lacking p56lck. Nature 1992, 357:161-164

11. Molina TJ, Bachmann MF, Kündig TM, Zinkernagel RM, Mak TW: Peripheral T cells in mice lacking p56lck do not express significant antiviral effector functions. J Immunol 1993, 151:699-706

12. American Journal of Physiology - Regulatory, Integrative and Comparative Physiology: Guiding principles for research involving animals and human beings. Am J Physiol Regulatory Integrative Comp Physiol 2002, 283:R281-R283

13. Cavarra E, Bartalesi B, Lucattelli M, Fineschi S, Lunghi B, Gambelli F, Ortiz LA, Martorana PA, Lungarella G: Effects of cigarette smoke in mice with different levels of alpha(1)-proteinase inhibitor and sensitivity to oxidants. Am J Respir Crit Care Med 2001, 164:886-980

14. Thurlbeck WM: Measurement of pulmonary emphysema. Am Rev Respir Dis 1967, 95:752-764

15. Thurlbeck WM: Internal surface area of nonemphysematous lung. Am Rev Respir Dis 1967, 95:765-773

16. Bartalesi B, Cavarra E, Fineschi S, Lucattelli M, Lunghi B, Martorana PA, Lungarella G: Different lung responses to cigarette smoke in two strains of mice sensitive to oxidants. Eur Respir J 2005, 25:15-22

17. Atzori L, Lucattelli M, Scotton CJ, Laurent GJ, Bartalesi B, De Cunto G, Lunghi B, Chambers RC, Lungarella G: Absence of proteinase activated receptor-1 signaling in mice confers protection from fMLP-induced goblet cell metaplasia. Am J Respir Cell Mol Biol 2009, 41:680-687

18. Lucattelli M, Bartalesi B, Cavarra E, Fineschi S, Lunghi B, Martorana P, Lungarella G: Is neutrophil elastase the missing link between emphysema and fibrosis? Evidence from two mouse models. Respir Res 2005, 26:83

19. Martorana PA, Lunghi B, Lucattelli M, De Cunto G, Beume R, Lungarella G: Effect of roflumilast on inflammatory cells in the lungs of cigarette smoke-exposed mice. BMC Pulm Med 2008, 8:17

20. Meshi B, Vitalis TZ, Ionescu D, Elliott WM, Liu C, Wang XD, Hayashi S, Hogg JC: Emphysematous lung destruction by cigarette smoke. The effects of latent adenoviral infection on the lung inflammatory response. Am J Respir Cell Mol Biol 2002, 26: $52-57$

21. Winer J, Jung CK, Shackelc I, Williams PM: Development and validation of real-time quantitative reverse transcriptase-polymerase chain reaction for monitoring gene expression in cardiac myocytes in vitro. Anal Biochem 1999, 270:41-49

22. Yoshida T, Tuder RM: Pathobiology of cigarette smoke-induced chronic obstructive pulmonary disease. Physiol Rev 2007, 87: $1047-1082$

23. Taraseviciene-Stewart L, Voelkel NF: Molecular pathogenesis of emphysema. J Clin Invest 2008, 118:394-402

24. Rahman I, Adcock IM: Oxidative stress and redox regulation of lung inflammation in COPD. Eur Respir J 2006, 28:219-242

25. MacNee W, Rahman I: Oxidants and antioxidants as therapeutic targets in chronic obstructive pulmonary disease. Am J Respir Crit Care Med 1999, 160:S58-S65

26. Churg A, Cosio M, Wright JL: Mechanisms of cigarette smokeinduced COPD: insights from animal models. Am J Physiol Lung Cell Mol Physiol 2008, 294:L612-L631
27. Motz GT, Eppert BL, Sun G, Wesselkamper SC, Linke MJ, Deka R, Borchers MT: Persistence of lung CD8 T cell oligoclonal expansions upon smoking cessation in a mouse model of cigarette smoke-induced emphysema. J Immunol 2008, 181:8036-8043

28. Motz GT, Eppert BL, Wesselkamper SC, Flury JL, Borchers MT: Chronic cigarette smoke exposure generates pathogenic $\mathrm{T}$ cells capable of driving COPD-like disease in Rag2-/- mice. Am J Respir Crit Care Med 2010, 181:1223-1233

29. Hogg JC, Chu F, Utokaparch S, Woods R, Elliott WM, Buzatu L, Cherniack RM, Rogers RM, Sciurba FC, Coxson HO, Paré PD: The nature of small-airway obstruction in chronic obstructive pulmonary disease. N Engl J Med 2004, 350:2645-2653

30. O'Shaughnessy TC, Ansari TW, Barnes NC, Jeffery PK: Inflammation in bronchial biopsies of subjects with chronic bronchitis: inverse relationship of CD8 + T lymphocytes with FEV1. Am J Respir Crit Care Med 1997, 155:852-857

31. Saetta M, Di Stefano A, Turato G, Facchini GM, Corbino L, Mapp CE, Maestrelli P, Ciacci A, Fabbri LM: CD8+ T-lymphocytes in peripheral airways of smokers with chronic obstructive pulmonary disease. Am J Respir Crit Care Med 1998, 157:822-826

32. Wang Z, Zheng T, Zhu Z, Homer RJ, Riese RJ, Chapman HA Jr, Shapiro SD, Elias JA: Interferon gamma induction of pulmonary emphysema in the adult murine lung. J Exp Med 2000, 192: $1587-1600$

33. Grumelli S, Corry DB, Song LZ, Song L, Green L, Huh J, Hacken J, Espada R, Bag R, Lewis DE, Kheradmand F: An immune basis for lung parenchymal destruction in chronic obstructive pulmonary disease and emphysema. PLoS Med 2004, 1:e8

34. Hautamaki RD, Kobayashi DK, Senior RM, Shapiro SD: Requirement for macrophage elastase for cigarette smoke-induced emphysema in mice. Science 1997, 277:2002-2004

35. Walter U, Santamaria P: CD8 + T cells in autoimmunity. Curr Opin Immunol 2005, 17:624-631

36. Santamaria P: Effector lymphocytes in islet cell autoimmunity. Rev Endocr Metab Disord 2003, 4:271-280

37. Rose NR, Bona C: Defining criteria for autoimmune diseases (Witebsky's postulated revisited). Immunol Today 1993, 14:426-430

38. Eppert BL, Wortham BW, Flury JL, Borchers MT: Functional characterization of $\mathrm{T}$ cell populations in a mouse model of chronic obstructive pulmonary disease. J Immunol 2013, 190: $1331-1340$

39. D'Hulst AI, Maes T, Bracke KR, Demedts IK, Tournoy KG, Joos GF, Brusselle GG: Cigarette smoke-induced pulmonary emphysema in scid-mice. Is the acquired immune system required? Respir Res 2005 , 6:147

40. Motz GT, Eppert BL, Wortham BW, Amos-Kroohs RM, Flury JL, Wesselkamper SC, Borchers MT: Chronic cigarette smoke exposure primes NK cell activation in a mouse model of chronic obstructive pulmonary disease. J Immunol 2010, 184:4460-4469

41. Curtis JL, Freeman CM, Huffnagle GB: "B" for bad, beneficial, or both? Lung lymphoid neogenesis in chronic obstructive pulmonary disease. Am J Respir Crit Care Med 2015, 192:648-651

42. Polverino F, Cosio BG, Pons J, Laucho-Contreras M, Tejera P, Iglesias A, Rios A, Jahn A, Sauleda J, Divo M, Pinto-Plata V, Sholl L, Rosas IO, Agusti A, Celli BR, Owen CA: B cell-activating factor. An orchestrator of lymphoid follicles in severe chronic obstructive pulmonary disease. Am J Respir Crit Care Med 2015, 192:695-705

43. Seys LJ, Verhamme FM, Schinwald A, Hammad H, Cunoosamy DM, Bantsimba-Malanda C, Sabirsh A, McCall E, Flavell L, Herbst R, Provoost S, Lambrecht BN, Joos GF, Brusselle GG, Bracke KR: Role of B cell-activating factor in chronic obstructive pulmonary disease. Am J Respir Crit Care Med 2015, 192:706-718

44. Kammerl IE, Dann A, Mossina A, Brech D, Lukas C, Vosyka O, Nathan P, Conlon TM, Wagner DE, Overkleeft HS, Prasse A, Rosas IO, Straub T, Krauss-Etschmann S, Königshoff1 M, Preissler G, Winter H, Lindner M, Hatz R, Behr J, Heinzelmann K, 
Yildirim AO, Noessner E, Eickelberg O, Meiners S: Impairment of immunoproteasome function by cigarette smoke and in COPD. Am J Respir Crit Care Med 2016, 193:1230-1241

45. Grundy S, Plumb J, Lea S, Kaur M, Ray D, Singh D: Down regulation of $\mathrm{T}$ cell receptor expression in COPD pulmonary CD8 cells. PLoS One 2013, 8:e71629

46. Mills CD, Kincaid K, Alt JM, Heilman MJ, Hill AM: M-1/M-2 macrophages and the Th1/Th2 paradigm. J Immunol 2000, 164: 6166-6173

47. Cardini S, Dalli J, Fineschi S, Perretti M, Lungarella G, Lucattelli M: Genetic ablation of the Fprl gene confers protection from smokinginduced lung emphysema in mice. Am J Respir Cell Mol Biol 2012, 47:332-339

48. Cicko S, Lucattelli M, Müller T, Lommatzsch M, De Cunto G, Cardini S, Sundas W, Grimm M, Zeiser R, Dürk T, Zissel G, Boeynaems JM, Sorichter S, Ferrari D, Di Virgilio F, Virchow JC, Lungarella G, Idzko M: Purinergic receptor inhibition prevents the development of smoke-induced lung injury and emphysema. J Immunol 2010, 185:688-697
49. Lucattelli M, Cicko S, Müller T, Lommatzsch M, De Cunto G, Cardini S, Sundas W, Grimm M, Zeiser R, Dürk T, Zissel G, Sorichter S, Ferrari D, Di Virgilio F, Virchow JC, Lungarella G, Idzko M: P2X7 receptor signaling in the pathogenesis of smokeinduced lung inflammation and emphysema. Am J Respir Cell Mol Biol 2011, 44:423-429

50. Lommatzsch M, Cicko S, Müller T, Lucattelli M, Bratke K, Stoll P, Grimm M, Dürk T, Zissel G, Ferrari D, Di Virgilio F, Sorichter S, Lungarella G, Virchow JC, Idzko M: Extracellular adenosine triphosphate and chronic obstructive pulmonary disease. Am J Respir Crit Care Med 2010, 181:928-934

51. Stogsdill MP, Stogsdill JA, Bodine BG, Fredrickson AC, Sefcik TL, Wood TT, Kasteler SD, Reynolds PR: Conditional overexpression of receptors for advanced glycation end-products in the adult murine lung causes airspace enlargement and induces inflammation. Am J Respir Cell Mol Biol 2013, 49:128-134

52. Robinson AB, Stogsdill JA, Lewis JB, Wood TT, Reynolds PR: RAGE and tobacco smoke: insights into modeling chronic obstructive pulmonary disease. Front Physiol 2012, 3:301 